\title{
IN THE MUSEUM: CONTAINING ANTIQUITY AN EXHIBITION IN THE SASOL ART MUSEUM, STELLENBOSCH
}

\author{
S Masters (Stellenbosch University)
}

A selection of ancient Classical and Near Eastern artefacts belonging to the Iziko Museums of Cape Town ${ }^{1}$ is currently on display at the Sasol Art Museum (a Stellenbosch University Museum) ${ }^{2}$ as the remodelled exhibition, Containing Antiquity. The exhibition, though modest in size, features several important and interesting pieces, many of which are known to South African and international scholars. ${ }^{3}$

\section{Recent history}

Containing Antiquity is the happy result of an extended agreement between Iziko, the Department of Ancient Studies at Stellenbosch University and Sasol Art Museum. Iziko owns a large collection of antiquities, many of which were purchased for the then South African Museum by the businessman and benefactor to the city, Capetonian Alfred Aaron de Pass (1861-1952). His noble intention was that the "public of Cape Town [benefit from seeing] original examples of the artistic achievement of ancient civilizations". ${ }^{4}$ Originally housed in the Old Supreme Court Building of the South African Cultural History Museum, ${ }^{5}$ Cape Town, the antiquities were on display until they were put into storage in 2003.

In 2004 fruitful negotiations between the Department of Ancient Studies, Iziko and Sasol Art Museum allowed several key pieces of the collection to see the light of day again. ${ }^{6}$ The artefacts selected were given new life in an exhibition housed in the Sasol Art Museum from 2005 until 2007, the appropriately entitled Living Antiquity. Living Antiquity is now succeeded by

1 Iziko Museums of Cape Town is the amalgamated body that, in 2000, joined various museum sites around Cape Town, including the South African Museum and the South African Cultural History Museum.

2 The museum at 52 Van Ryneveld Street, Stellenbosch. Visit http://admin.sun.ac.za/usmuseum/ for opening times and contact details. Visit http://academic.sun.ac.za/as/iziko/Index.htm for images of the exhibition vitrines.

3 Particularly the ancient Greek black- and red-figure vases which were published by John Boardman and Maurice Pope as the booklet Greek Vases in Cape Town (1961). Other specific and noteworthy pieces have been published by Boshoff 1995, 1996; Boshoff \& Cornelius 2002 and Cornelius 2005.

$4 \quad$ Boardman \& Pope 1961:5.

5 Renamed the Slave Lodge in 1998.

6 The Ancient Studies Department is very grateful for the continued support, co-operation and assistance of Anlen Boshoff (previously of Iziko), Esther Esmyol (Iziko) and Dr. Lydia de Waal of Sasol Art Museum. 
the re-themed Containing Antiquity, which is a study of a selection of ancient vessels with a particular interest in shape. With this focus, the exhibition capitalises on one of the particular strengths of the Iziko collection: its broad representation of vessel shape, type and function. ${ }^{7}$

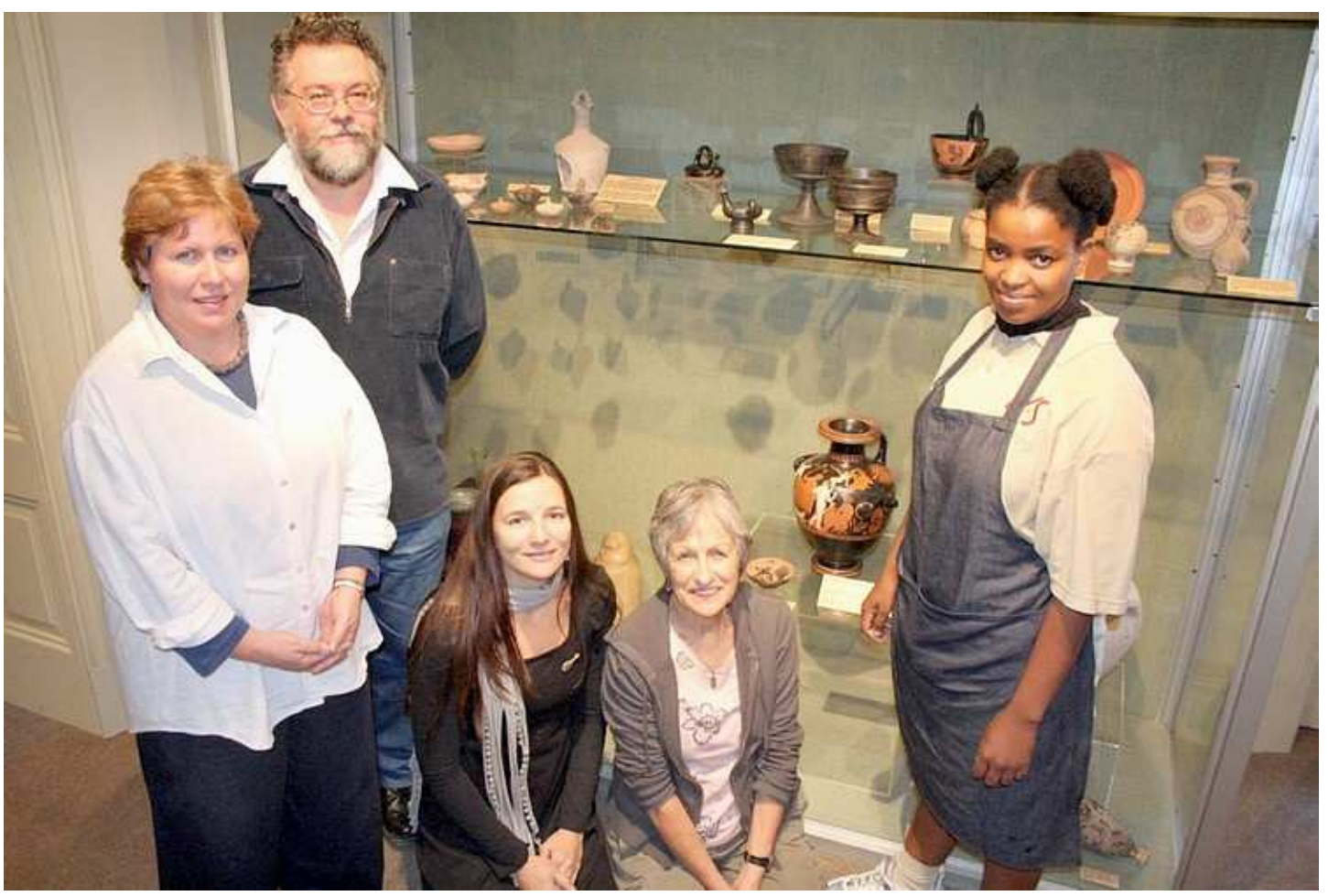

Fig. 1: From left Esther Esmyol (Iziko), Prof. Sakkie Cornelius and Samantha Masters (both of Ancient Studies, Stellenbosch University), Anlen Boshoff (previously of Iziko) and Babalwa Ramncwana (Iziko) who assembled the pieces for the new Containing Antiquity exhibition. All images by kind permission of Iziko Museums of Cape Town and the Sasol Art Museum.

\section{The current exhibition}

The provenance of the objects on display is Greece, Cyprus, Egypt, Israel / Palestine, Etruscan Italy and the Roman world and they range in date from the $3^{\text {rd }}$ millennium $\mathrm{BC}$ to the $3^{\text {rd }}$ century AD. All artefacts were selected because they are containers of some kind, and functions cover a wide spectrum of human experience: from birth to death, both male and female, freeborn and slave. These pieces each contained or packaged substances essential to ancient daily life, whether ordinary domestic life, the good life, or death and the afterlife.

Fig. 1 shows the team responsible for assembling the new exhibition. Thanks are also due to the technical staff of Sasol Art Museum who lent their expertise. 
There is, for example, the Egyptian "Bes" vase, ${ }^{8}$ which may have been used to store milk for feeding babies. Other objects were used for the storage, mixing, pouring, carrying and serving of daily foodstuffs, such as olive oil, water and wine. Some particularly refined vessels would have featured as smart dinner tableware, such as the Etruscan bucchero ware, ${ }^{9}$ the exquisite Egyptian lotus cup,$^{10}$ and the better Greek black- and red-figure pieces such as the showpiece Chicago Painter stamnos. ${ }^{11}$ While the various wine-drinking cups and the larger Greek vases such as the stamnos and the column krater $^{12}$ would have mostly been used and contemplated by men at the Greek symposion (drinking / dinner party), other smaller pottery vessels are drawn from the life of women. Included here are vessels that would have contained personal items such as trinkets and jewellery (e.g. the pyxis), ${ }^{13}$ or perfumed water (plemochoe). ${ }^{14}$ Storage of oil for athletes (aryballos ${ }^{15}$ and alabastron ${ }^{16}$ ) and the pouring of funerary or religious libations (lekythoi ${ }^{17}$ ) are other uses represented here. There is a small selection of Roman glass bowls and toilette bottles, and a few pottery lamps that would have regularly been topped up with oil, perhaps by a slave, using the guttus. ${ }^{18}$ Finally there is the alabaster canopic jar ${ }^{19}$ from Egypt that would have contained the intestines of the deceased removed during the mummification process.

Such a range of vessel provenance, period, decoration, shape and function make this collection an ideal window into various aspects of ancient life. For this reason the collection is of great interest to the general viewer who cannot help being struck by the relatively simple, yet aesthetically pleasing solutions the ancients had for packaging and containing their daily substances. The exhibition is also valuable as

81942 (probably from Kafr-Tarkhan, Egypt, Dynasty XXII (945-715 BC), published by Boshoff \& Cornelius 2002:135-137, 138; pl. I:A and II:B; Cornelius 2005: 128; fig 10b). Numbers quoted along with each artefact in this article are Iziko accession numbers, not the old SACHM numbers.

9 Two chalices (1406 and 1407) possibly from Vulci, Boardman \& Pope 1961:18-19; pl XV.

101722 Egyptian cup with lotus decoration, blue faience from Tuneh, Egypt, Dynasty XXVII (c. 404-399 BC); Boshoff \& Cornelius 2002:138; pl I:D; Cornelius 2005:126; fig. 4.

111339 Attic red-figure stamnos, from Megara, mid $5^{\text {th }}$ century BC. Boardman \& Pope describe this as "the finest of the Cape Town vases" (1961: 12-13; pl VI-VIII). The publication record for the vase includes Peschel 1987:pl.189-190 (A,B); Beazley 1963 [ARV] 629.19 bis, 1662; Beazley 1971 [Paralipomena] 399; Boardman 1989: fig. 27 (A); Carpenter, Mannack \& Mendonca 1989:272.

121326 red-figure column krater, from Athens by the Florence Painter (c. 460 BC); Boardman \& Pope 13-14; pl IX); Beazley 1963 [ARV] 543.45, 1658.

131359 geometric horse pyxis, from Athens (c. $800 \mathrm{BC})$.

141338 black-figured plemochoe (c. 525 BC) Boardman \& Pope 1961:11-12; pl IV.

151400 Corinthian spherical aryballos, from Camirus, Rhodes, c. 600 BC; Boardman \& Pope 1961:18.

161401 Corinthian alabastron, from Camirus, c. 600 BC, Boardman \& Pope 1961:17.

171330 and 1331, black figure lekythoi from Athens $c .500 \mathrm{BC}$, from the workshop of the Athena Painter, Boardman \& Pope 1961:10; pl V; Haspels 1936:262; Beazley \& Magi 1939, i, 65.

$1873 / 515$, a small narrow-necked vessel with a ring handle used to refill oil lamps. One would move through the house filling the various lamps, rather than taking all the lamps to the oil source and then replacing them.

191724 Egyptian canopic jar, alabaster from Egypt, Dynasty XXVI, 664-525 BC, Cornelius 2005 : 129; fig. 13. 
a university teaching collection, both in ancient cultures modules that explore the daily life of the ancients, and in the more specific modules on Classical, Egyptian and Near Eastern art. The Greek vases for example provide useful material with which to demonstrate different approaches towards the study of Attic black- and red-figure vase painting. As an example of one such approach, a comparative iconographic analysis of three potential depictions of the wine-god Dionysos will form the focus of the remainder of this paper.

\section{Dionysian iconography on three Greek vases}

Ancient Greek vase-painters decorated their wares with scenes - narrative or otherwise - that use a visual language that is akin to verbal language in its specificity, complexity and in its need for interpretation. ${ }^{20}$ The three Athenian vases that include (or potentially include) the figure of Dionysos as protagonist in their painted scenes are a black-figure olpe ${ }^{21}$ of $c$. $500 \mathrm{BC}$ (Fig. 2), a red-figure hydria ${ }^{22}$ c. 425-375 BC (Fig. 3), and a red-figure column krater of c. $460 \mathrm{BC}$ (Fig. 4). ${ }^{23}$ Focussing on this figure on each of these vases will offer a useful case study in the specifics of vase interpretation or the so-called "reading" of vases. ${ }^{24}$

The first example appears on the black-figure olpe (Fig. 2), a slender winepouring jug used to decant wine from a larger mixing vessel (such as the stamnos or krater) into a drinking cup (such as a kylix or skyphos). A mature male figure climbs into a chariot, while holding the reins. His identity is made clear through the combination of particular visual signs or icons, which are well established and hold meaning for the painter and his audience. It is these signs that need careful interpretation, since, as will be seen when considering the third example, one may be lead astray by them if they are not read with an awareness of, and openness to, other

20 We must remind ourselves that it is a fallacy that images "speak for themselves", i.e. that their meaning is clear or self-evident. Mary Beard describes how the process of understanding images, even contemporary ones, requires that we be equipped to do so. "Understanding images", she says "is a process that depends on our having learned to look and on a long-practiced skill in the decipherment of visual and cultural signs" (Beard 1991:13).

214271 Boardman \& Pope 1961:9; pl. IV; Beazley $1956[A B V] 447$.

221327 red-figured hydria from Athens (c. 425 BC) Boardman \& Pope 14-15; pl. X-XII; Boardman 2001:103, fig. 137; LIMC VIII, pl. 626, PAN 192; Boardman 1989: fig. 347.

23 See footnote 11 for accession number and vase details.

24 What follows here is an abbreviated reading of the figure of Dionysos on these three vases. Ideally, "reading" a vase would encompass analysing all aspects of the vase, including shape, painted scenes and subsidiary decoration. For example, that the figure of Dionysos, god of wine, makes an appearance on each of these three vessel types is relevant, and his presence is highly appropriate in each case. This demonstrates well how Greek vase-painters often make reference to shape or use in their painted scenes. Many scenes are "self-referral" and reflect the kind of activity engaged in when using the piece. Many examples could be cited here, hydriai for example, often specifically portray scenes of women collecting water from the fountain house with their hydriai (as on London B 344, Attic black-figure hydria, c. 520-500 BC, from Vulci in Etruria). Sometimes the link is simply thematically appropriate, as in these three vessels that are all connected with wine in some way. 
potentialities. In short, appearances may be deceiving, particularly to the modern eye unversed in the language of ancient Greek vase painting.

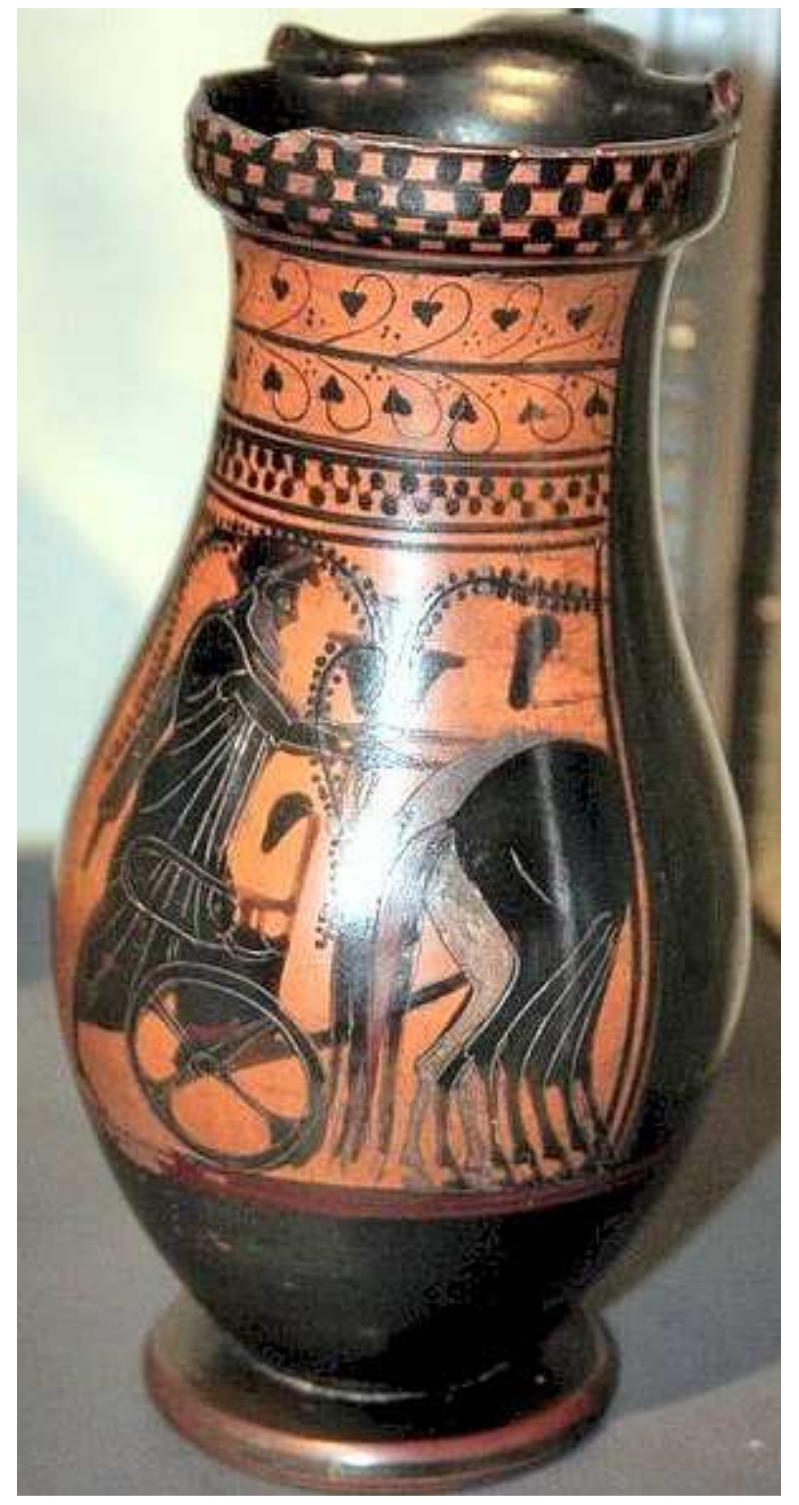

Fig. 2: Attic black-figure olpe, c. 500 BC

The figure wears a chiton (long tunic) and is draped with his himation (cloak), which is gathered over his left shoulder. An added red line around his head indicates a fillet. He wears a full beard. While they contribute to his identification, these elements alone are not conclusive for Dionysos, since other gods and humans on Archaic vases may also be bearded and wear long tunics, cloaks and fillets. More specific and certain icons are present in the kantharos (wine cup) ${ }^{25}$ and vine stem (complete with two bunches of grapes) ${ }^{26}$ that Dionysos "holds". ${ }^{27}$ Drawn from his domain these icons both identify him and remind the viewer of his associations with wine and also with nature. ${ }^{28}$

Having identified a protagonist on a vase as a figure from myth, one can also look for signs of a narrative. ${ }^{29}$ However, to fit his picture field, which is narrow by virtue of the shape of the vase, the artist has "cropped" what we could imagine to be a larger scene, and not much outside the figure of the god remains. He stands in a chariot, and only the rear ends of the chariot horses are shown. While a chariot

25 In other scenes of this period he sometimes holds a drinking horn.

26 Dionysos holds a vine stem in an Attic vase painting scene at least as early as Sophilos' dinos of 570 BC (London BM 1971.11-1.1, Para19.16bis).

27 The kantharos and vine stem seem to hover above or balance on his hands, rather than being held. The physical difficulty of simultaneously holding kantharos, vine stem and reins is not a concern for the $6^{\text {th }}$ century vase painter, who is not aspiring to the representation of "reality". Their presence as icons, as well as their aesthetic appeal, overrides logistics in this case.

28 Regarding Dionysos' links with nature see Seaford 2006:17.

29 Not all Archaic vase painting scenes are narrative, but the general tendency in this period is for the vase painters to use the vibrant and visually interesting mythological narratives as their subject matter. 
may imply a journey, even a specific one in the mind of the painter, no other signals help us to identify a particular storyline here.

Reading on a less literal level, the chariot may still have meaning for its audience. It could enhance the stature of the god since the chariot was both an aristocratic and ceremonial mode of transport. Or the chariot may have emphasised Dionysos' associations with "civilization" and the polis over his more "rustic" aspect. ${ }^{30}$ Reading the chariot this way allows this scene to simply be an evocation of a specific aspect (or aspects) of the god, with no clear narrative purpose at all. The Dionysos that rides the stately chariot on this vase is the mature, bearded male figure that is typical of the dignified earlier Archaic representations of the god. ${ }^{31}$

Standing in complete contrast with the olpe Dionysos is the same god depicted on the late $5^{\text {th }}$ century hydria (Fig. 3). Not only does the iconography of the figure differ, but the scene and mood are also strikingly different. The hydria (a vase designed for fetching, carrying and pouring water) is of course an entirely different vessel from the olpe and, with its larger size and bigger belly, it offers a much more expansive picture field for decoration. The artist has filled the available space with a very "well-mannered" scene ${ }^{32}$ on multiple ground levels, involving Dionysos at a symposion. To state another obvious difference, this vase is painted in the red-figure style, which offers different possibilities to the artist and which is accompanied by developments in technique, scene composition ${ }^{33}$ and shifts of emphasis or approach. These are all well demonstrated here, as is the striking change in the iconography and representation of Dionysos that occurs in Athenian painting around the date of this vase $(425 \mathrm{BC}){ }^{34}$

No longer a mature, sensibly clad deity, the god becomes an effeminate, unbearded, curly-haired and scantily clad youth, languishing at a symposion. ${ }^{35} \mathrm{He}$ is a completely different protagonist in a completely different kind of scene. He reclines on a floral-patterned couch, wreathed with ivy and holding a thyrsos (both common

30 On earlier vases such as Sophilos' dinos and Kleitias' krater (Florence, Museo Archeologico 4209, $A B V$ 76.1), Dionysos travels by foot, and appears more woolly and "rustic". However, Simon (2002:92) points out that, "Dionysos was not a "primitive" vegetation god, but connected with more sophisticated agriculture".

31 His attire and accessories are conventional for the $6^{\text {th }}$ century and much of the $5^{\text {th }}$ century. Carpenter discusses Dionysian iconography and scenes in detail in several useful publications: Carpenter 1997; 1993; 1991 and 1986.

32 As Cook (1962:319) described the scene in his review of the Boardman \& Pope (1961) catalogue. Cook seems to favour this vase as the most interesting vase of the collection, calling it as "the most notable piece" of the collection.

33 Such as the composition of scenes on multiple ground levels to effect a sense of perspective in a scene.

34 Dionysos also becomes more youthful on coins and in sculpture, at around the same time as the change occurs in vase-painting (Carpenter 1991:38). This indicates that the shift is not only to do with iconographic preferences of vase-painters but a broader aesthetic and ideological choice

35 The Dionysos in Euripides' Bacchae, for example, is described by Pentheus as attractive to women, not athletic (i.e. effeminate?), having long silken hair and beautiful skin (Bacchae 453458). A preference for youthfulness over age is in keeping with the general ideal of youthful beauty characteristic of the mid- to late classical period, however, Dionysos is one of the few gods whose physical transformation towards youthfulness is so extreme. 
attributes by this stage) entwined with vine stems. Furthermore the youthful Dionysos is not engaged in "doing" so much as "being". Rather than depicted in action as on the olpe, he is at leisure, in symposion mode and being entertained by standard members of his entourage: satyrs, maenads, Pan and Eros.

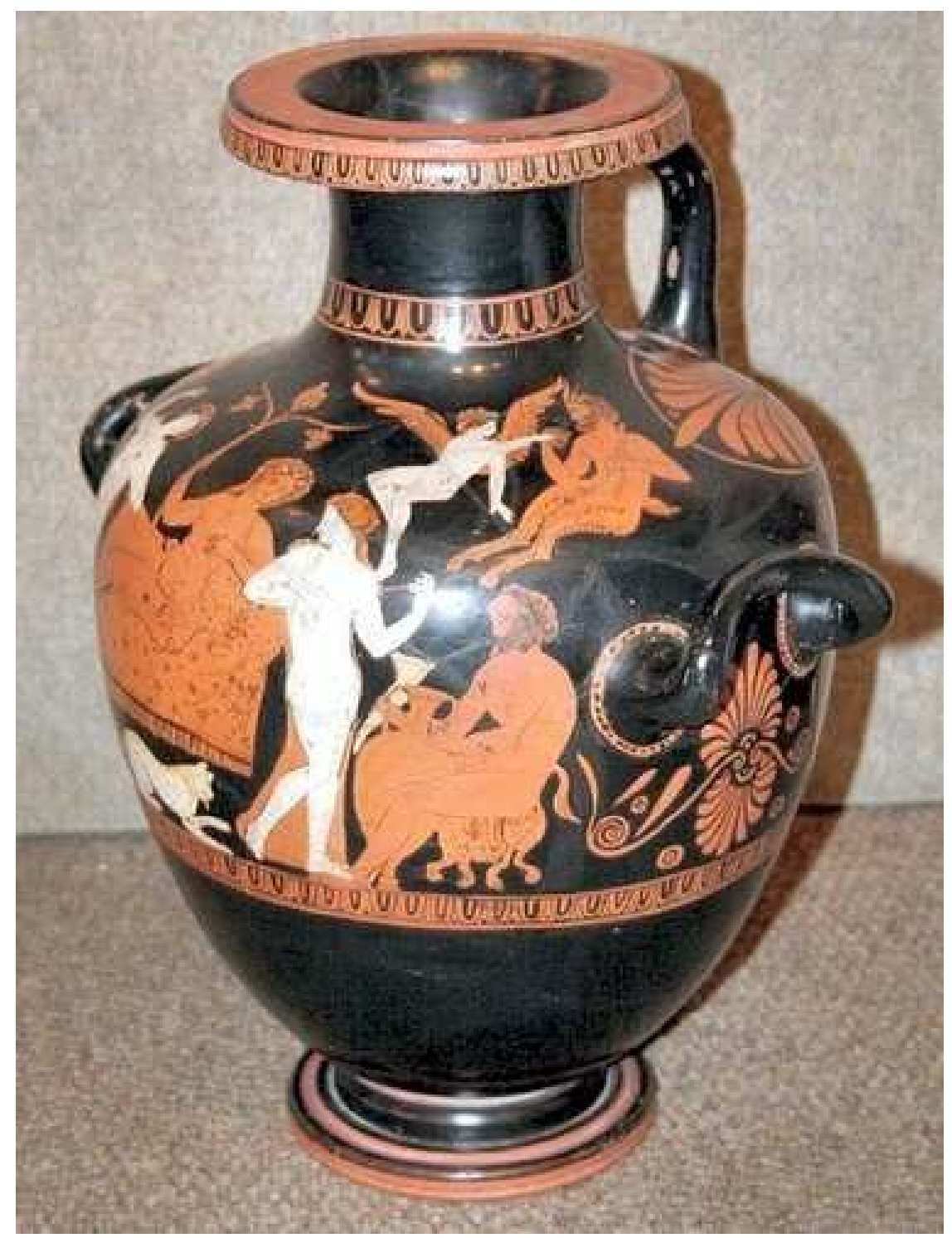

Fig. 3: Attic red-figure hydria, c. 425 BC

Again when seeking a "narrative" for this scene one can entertain a few possibilities, which may still amount to no definitive identification. ${ }^{36}$ However, the date of the vase and this era's preference for fussy "heavenly garden" type scenes that are often specifically lacking in narrative ${ }^{37}$ means that we do not necessarily need to attribute a

\footnotetext{
36 Dionysos attends symposia with his wife, Ariadne, with Hephaistos, with Dione and other gods, but none of these specific figures have conclusively been proved present here yet.

37 As described by Burn (1991:120ff).
} 
fixed and particular narrative meaning to the scene. Dionysos' association with the institution of the symposion and its delights and activities again renders a generalised symposion scene meaningful to an audience that would have very likely used, viewed and appreciated the vessel at a symposion. ${ }^{38}$ The dancing maenads in their diaphanous robes, the satyr's drinking horn and amphora, the presence of Eros, Dionysos' naked torso, and Pan's pipes all suggest eroticism and revelry, but it is of a calm and civilised kind, rather than the more animated frenzies often depicted in the earlier $5^{\text {th }}$ century BC. ${ }^{39}$ The presence of a pet panther ${ }^{40}$ and the hare ${ }^{41}$ in the lap of the seated woman on the left add to the pleasant, calm mood, which would have delighted the tastes of the late $5^{\text {th }}$ century BC audience.

The final example is on the red-figure krater (wine mixing vessel) where a bearded male rides a mule and holds a vine stem (Fig. 4). He is accompanied by a satyr with double pipes and a maenad who leads the way with torches. Iconographic signals observed in the other two scenes - such as the beard, vine stem, satyrs and maenads - seem to indicate Dionysos. The mule too is one of his preferred modes of transport. ${ }^{42}$ However, the short tunic is not typical for the god. In addition to this anomaly, we must take account of the fact that the matrix of the scene also resembles that involving Hephaistos, the smith god, returning to Olympos. ${ }^{43}$ In these scenes Hephaistos typically rides a mule, and Dionysos and entourage accompany him on foot. ${ }^{44}$ The fact that this bearded figure does not carry Hephaistos' own standard iconographic attributes of hammer and / or tongs does not vitiate the identification. Nor does the fact that he has normal, and not deformed feet. ${ }^{45}$

38 It is appropriate that the god of wine feature on a water vessel, since his produce (wine) will be mixed with water from the hydria to be drunk at a symposion such as that depicted on the vessel. Such a fine piece would surely have made it to the table of symposia and the scene contemplated by those revellers in attendance.

39 The women are not frantic but show themselves off with a gesture of display. Dionysos admires them sedately. Boardman \& Pope (1961:15) point out that Pan, depicted earlier as a kind of woolly goat-demon, has become more human, and that the satyrs have "arched, quizzical brows" and are "quieter, more intellectual creatures". The satyrs are seated - at rest rather than joining in the dance. Compare for example the more animated revelry on Kleophrades Painter's famous Munich amphora (2344, from Vulci, $A R V$ 182,6) and kalpis in Basle (Wilhelm Collection, from Vulci, $A R V$ 189,73).

40 The panther is collared and therefore domesticated.

41 Hares and panthers are common participants in scenes related to Dionysos before this time. However this scene shows a particularly tame and domesticated version of both panther and hare (on earlier scenes, the latter is presented as an offering to the god, and is likely to be torn apart as part of the Dionysian rites, e.g. the famous neck amphora scene by Amasis where two maenads present a hare and a stag to Dionysos (Paris, Cabinet des Medailles 222, ABV 152.25).

42 Dionysos is often depicted riding an ithyphallic mule (Carpenter 1991:38).

43 After literally been thrown out of Olympos by the angry Zeus, Hephaistos is convinced by Dionysos (through the fruits of the vine) to return.

44 Carpenter provides a useful and concise discussion of the iconography of such scenes and the variations on the scene types (1991:13-17).

45 Aside from the depiction of this scene on the Francois Vase, Attic vase painters do not seem to depict Hephaistos' deformities (Carpenter 1991:15). 
The absence of Dionysos from this Return scene - an episode in which he was a key participant - may however seem strange. On the other hand, well-established scene types such as this one could be abbreviated (or elaborated) to suit particular conditions (e.g. painter, vase type, picture field and audience), while retaining their narrative intact. The vine stem carried by Hephaistos is perhaps enough to remind the viewer of Dionysos' role in the narrative, or at least evoke the role of drunkenness that was central to the story. ${ }^{46}$ In this light it seems Hephaistos, rather than Dionysos may be the most likely candidate here. ${ }^{47}$

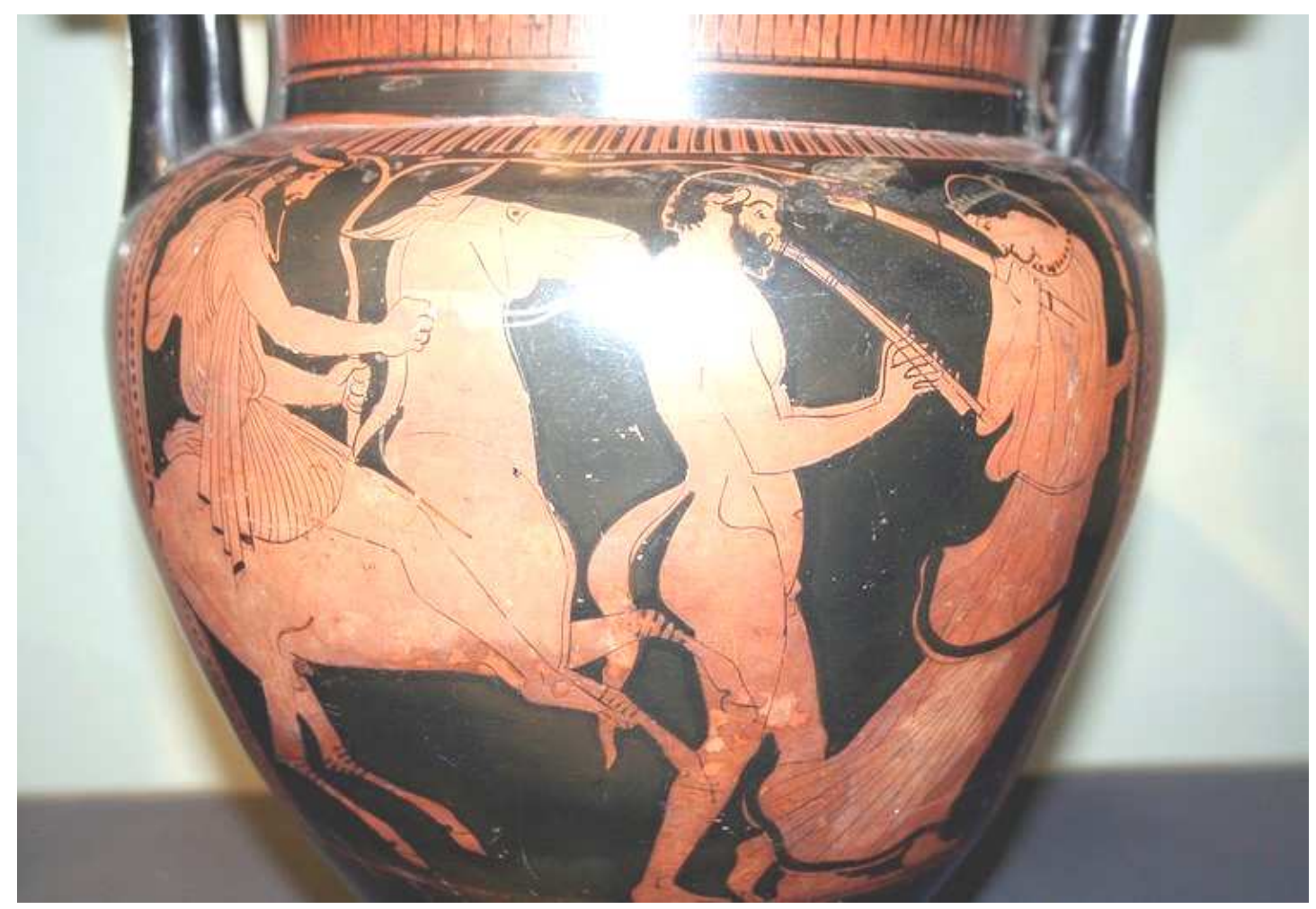

Fig. 4: Attic red-figure krater, c. $460 \mathrm{BC}$

Yet, since there are other fairly general Dionysian scenes showing Dionysos riding a mule, and a few (though not many) examples of Dionysos in a short chiton ${ }^{48}$ one cannot categorically prescribe which of the two protagonists the ancient viewer would have recognised here. And this is an important point. When we look at these images, we have to try to look with ancient eyes, rather than with modern ones, and accept that the perceptions of the ancient viewer were, like our own, also shaped by particular conditions, life experience, and degree of visual literacy. We can work to recover these conditions, but in some cases it is preferable, indeed essential to leave this identification open-ended. Here it is best to say that the viewer may have read the

$46 \quad$ Pausanias gives a summary of the story at 1.20 .3 .

47 This identification is preferred by Boardman \& Pope 1961:13.

48 For example on the Attic red-figure calyx crater of $c .490 \mathrm{BC}$ by the Kleophrades Painter (Harvard Fogg Museum 1960.236, ARV 185.31). 
iconography of the figure and settled on one or the other of the two possibilities. Or even that the viewer may have recognised neither, since some scenes were, as Carpenter says, repeated and pared down to the point of becoming "a generic scene with no particular meaning". ${ }^{49}$

\section{Final word}

Viewing original objects has many advantages, not least of all the appreciation of scale and technique which can be difficult to observe from even the best images in books or online. It remains to be said that it is unfortunately a diminishing privilege to be able to view such original ancient artefacts in this country, and for this reason alone, Containing Antiquity is valuable to the public, to scholars and as a didactic tool.

A final comment is that although Containing Antiquity is not specifically curated with this goal in mind, the ancient pieces can also form a useful intertext when viewed in conjunction with other pieces of contemporary and traditional South African pottery and ceramics found in the Sasol Art Museum. Exploring the various needs, technologies and available materials of each group could allow interesting parallels and contrasts to be drawn between shape, function and aesthetic taste across an even wider temporal and geographical spectrum. But reflection on that worthy topic shall be taken up at another opportunity.

\section{BIBLIOGRAPHY}

Ackerman, H C, Gisler L R, et al (eds.) 1987-1997. Lexicon iconographicum mythologiae Classicae. Zurich: Artemis Verlag.

Beard, M 1991. Adopting an approach II. In Rasmussan, T \& Spivey N (eds.) Looking at Greek vases. Cambridge: Cambridge University Press.

Beazley, J D 1971. Paralipomena. Oxford: Clarendon Press.

Beazley, J D 1963. Attic red-figure vase-painters [ARV]. Oxford: Clarendon Press.

Beazley, J D 1956. Attic black-figure vase-painters [ABV]. Oxford: Clarendon Press.

Beazley, J D \& Magi, F 1939. La raccolta Benedetto Guglielmi nel Museo Gregoriano Etrusco. Vatican City: Pontifica Accademia Romana di Archeologia.

Boardman, J 2001. The history of Greek vases: potters, painters and pictures. London: Thames and Hudson.

Boardman, J 1989. Athenian red figure vases, the Classical period. London: Thames and Hudson.

Boardman, J \& Pope, M 1961. Greek vases in Cape Town. South African Museum, Guide No. 6 Trustees of the S A Museum, Cape Town.

49 Carpenter 1991:15. 
Boshoff, A 1995. The Early Dynastic ceramics of Kafr-Tarkhan [c. 3000-2800 BC] with special reference to examples in the South African Cultural History Museum, Cape Town (Unpublished M A dissertation, Stellenbosch University).

Boshoff, A 1996. Egyptian ceramics from Kafr-Tarkhan [c.3050-2686 BC] in the South African Cultural History Museum, Cape Town. Cape Town: SACHM.

Boshoff, A \& Cornelius, I 2002. The Egyptian collection in Iziko Museums of Cape Town, South Africa. In Eldamaty, M \& Trad, M (eds.) Egyptian Museum Collections around the world: studies for the centennial of the Egyptian Museum. Cairo: Supreme Council of Antiquities, American University in Cairo Press, vol. I, 133-142.

Burn, L 1991. Later fifth-century red figure. In Rasmussan, T \& Spivey N (eds.) Looking at Greek vases. Cambridge: Cambridge University Press.

Carpenter, T. H. 1997. Dionysian imagery in fifth-century Athens. Oxford: Oxford University Press.

Carpenter, T H.1993. On the beardless Dionysus. In Carpenter T H \& Faraone C A Masks of Dionysus. Ithaca, NY: Cornell University Press.

Carpenter, T H 1991. Art and myth in ancient Greece. London: Thames and Hudson.

Carpenter, T H 1986. Dionysian imagery in archaic Greek art. Oxford: Oxford University Press.

Carpenter, T H, Mannack, T \& Mendonca, M 1989. Beazley Addenda, $2^{\text {nd }}$ edition. Oxford: Clarendon Press.

Cook, R M 1962. Review of Boardman, J \& Pope, M 1961. Greek vases in Cape Town. The Classical Review, New Series, 12.3:319.

Cornelius, I 2005. Van die Nyl tot Stellenbosch: Antieke Egiptiese voorwerpe in Stellenbosch. Akroterion 50:125-136.

Haspels, E 1936. Attic black-figured lekythoi. Paris: École francaise d'Athènes.

Peschel, I 1987. Die Hetare bei Symposium und Komos in der attisch rotfigurigen Malerei des 6.-4. Jhs. v.Chr. Frankfurt: European University Studies. Series XXXVIII.

Seaford, R 2006. Dionysos. London: Routledge.

Simon, E 2002. Festivals of Attica: An Archaeological Commentary. Madison: University of Wisconsin Press. 